\title{
On the Geotechnical Properties of Lateritic Gravels from the Quarries of Lam-Lam and Mont-Rolland (Western Senegal) - Implications for Their Use in Road Construction
}

\author{
Seybatou Diop, Ignace Gbaguidi, Fary Diome, Momar Samb \\ Institut des Sciences de la Terre, Faculté des Sciences et Techniques, Université Cheikh Anta Diop de Dakar, Sénégal
}

Email addresses:

seybdiop@yahoo.fr (S. Diop), igbaguidi.ignace@yahoo.fr (I. Gbaguidi), fary.diome@ucad.edu.sn (F. Diome), momar.samb@ucad.edu.sn (M. Samb)

\section{To cite this article:}

Seybatou Diop, Ignace Gbaguidi, Fary Diome, Momar Samb. On the Geotechnical Properties of Lateritic Gravels from the Quarries of LamLam and Mont-Rolland (Western Senegal) - Implications for Their Use in Road Construction. International Journal of Science, Technology and Society. Vol. 3, No. 5, 2015, pp. 260-264. doi: 10.11648/j.ijsts.20150305.16

\begin{abstract}
Samples of laterite soils from the quarries of Lam-Lam and Mont-Rolland (Thiès Department/Western Senegal) were investigated in the laboratory following the standard procedures suggested by the French norms. The main objective was directed at evaluating the geotechnical properties and the suitability for use as aggregates in road construction. The investigation revealed low load-bearing capacity (CBR of 61-65) as the primary technical parameter that constrained their suitability in road structure based on the general technical specifications. The bulk material meets the requirement for use as aggregates in road sub-grades, but does not fulfill the criteria for use as sub-bases in road construction; thus there is the need for necessary pretreatment in order to enhance their mechanical performance. The observed low bearing capacity can be attributed to the relative abundance of fines particles which tends to decrease the mechanical resistance and performance of aggregates, particularly in wet conditions.
\end{abstract}

Keywords: Lam Lam, Mont Rolland, Lateritic Gravel, Road construction, Geotechnique

\section{Introduction}

Lateritic soils are common tropical soils in many areas of West-Africa Sub-region which had found wider applications in many construction activities (roads, building foundations, etc). In Senegal, there are a number of sites where these valuable geo-materials had been mined for road and other construction activities, especially in the Thiès region (e.g., quarries of Sébikotane, Sindia, Yenne, Lam-Lam, MontRolland, Ngoundiane). However, the Senegalese Road Administration AGEROUTE (Agence des Travaux et de Gestion des Routes du Sénégal) recently identified the scarcity or dwindling reserves of good quality lateritic materials for road construction as most of the earlier quarries are being mined out. Therefore, the subject of this paper is to outline the preliminary results of experimental investigations carried out on laterite soils occurring in the quarries of Lamlam and Mont-Rolland (Thiès region), in an attempt to characterize their geotechnical properties. This would provide civil engineers with indications on their usability as aggregates materials in road construction within the region and its environs.

The study is part of a research partnership program between the Senegalese Road Administration AGEROUTE and the Earth Sciences Institute (Cheikh Anta Diop University of Dakar) on the quality of lateritic materials used as aggregates in road construction throughout the country. It is the subject matter of effective scientific partnership aimed at training student and professional engineering geoscientists. The ultimate aim of this program is to develop protocols (general technical guidelines) for application of lateritic materials in road construction while defining the appropriate detail protocol for potential pretreatment, as well as the specific design specifications for road pavement structure. Thus, this study among other previous studies (e.g. Diop et al., 2014) is part of the efforts of AGEROUTE's public mission in addressing this issue as well as the issue of assessment of new lateritic soil reserves for their suitability in road construction as other alternative sources for the already mined out quarries. Several authors including Fall (1993), Fall et al. (1995), Ngom (2011) and Sène (2013) have reported on the geotechnical properties of laterite soils from 
other quarries in other parts of Thiès region while elsewhere in the sub-region, the work of Bohi (2008) in Ivory Coast can also be cited.

\section{Geology}

The soils being investigated are lateritic soils occurring in

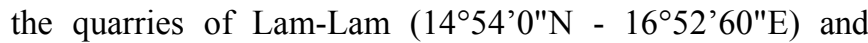
Mont-Rolland $\left(14^{\circ} 55^{\prime} 60^{\prime \prime} \mathrm{N}-16^{\circ} 58^{\prime} 60^{\prime \prime} \mathrm{E}\right)$ located in the northern part of the city of Thiès. Figure 1 shows the location of the main quarries exploited in the region. These lateritic soil profiles developed as weathered regolith over the Tertiary rocks of Eocene age (essentially marls- and limestones) (Tessier et al., 1976; Flicoteaux 1982; Ducasse et al. 1978) and occur as small outcrops in a number of locations within the Thiès Plateau. The development process, depositional style fabrics and genesis of the various ferruginous surface-duricrusts and lateritic soils occurring in Senegal has been studied by many authors, including Tessier (1965), Nahon (1971) and Michel (1976).

Geologically, the bedrock underlying the area are rock formations of the Senegalese Basin that has been filled up essentially by Upper Cretaceous (Maastrichtian sandstones) and Tertiary rocks (Paleocene and Eocene marlstones and limestones with intrusions of volcanic materials from Middle Eocene to Oligocene and possibly Miocene). A complex system of faults trending east, northeast and north affects the region (Crevola 1980; Bellion and Guiraud 1984). The intersection of these faults at many places resulted in a typical steeped structural style that is characteristic of the region.

\section{Methodology}

Bulk samples of laterite soils were collected in-situ from the two quarries and subject to geotechnical tests in the laboratory of AGEROUTE. The sampling was carried out by quartering in order to obtain necessary and representative amount of materials for the various laboratory tests. Two groups of samples were collected from each quarry site. The first group was used for the determination of basic geotechnical properties such as natural water content, grain size distribution characteristics and Atterberg limits; while the second group was used for the determination of maximum dry density and bearing capacity tests.

The Atterberg limits were determined using the fraction passing through sieve $\varnothing=400 \mu \mathrm{m}$. All tests were carried out following the standard procedures suggested by the French norms (NF) as highlighted below:

- Identification tests: Water content determination, NF P 94-050 (1995); Grain size analysis, NF P 94 - 056 (1995); Oedometer methods, NF P 94-051 and 052 (1993);

- Tests for mechanical behavior: Proctor compaction test, NF P 94-093 (1997); CBR test, NF P 94-078 (1997).

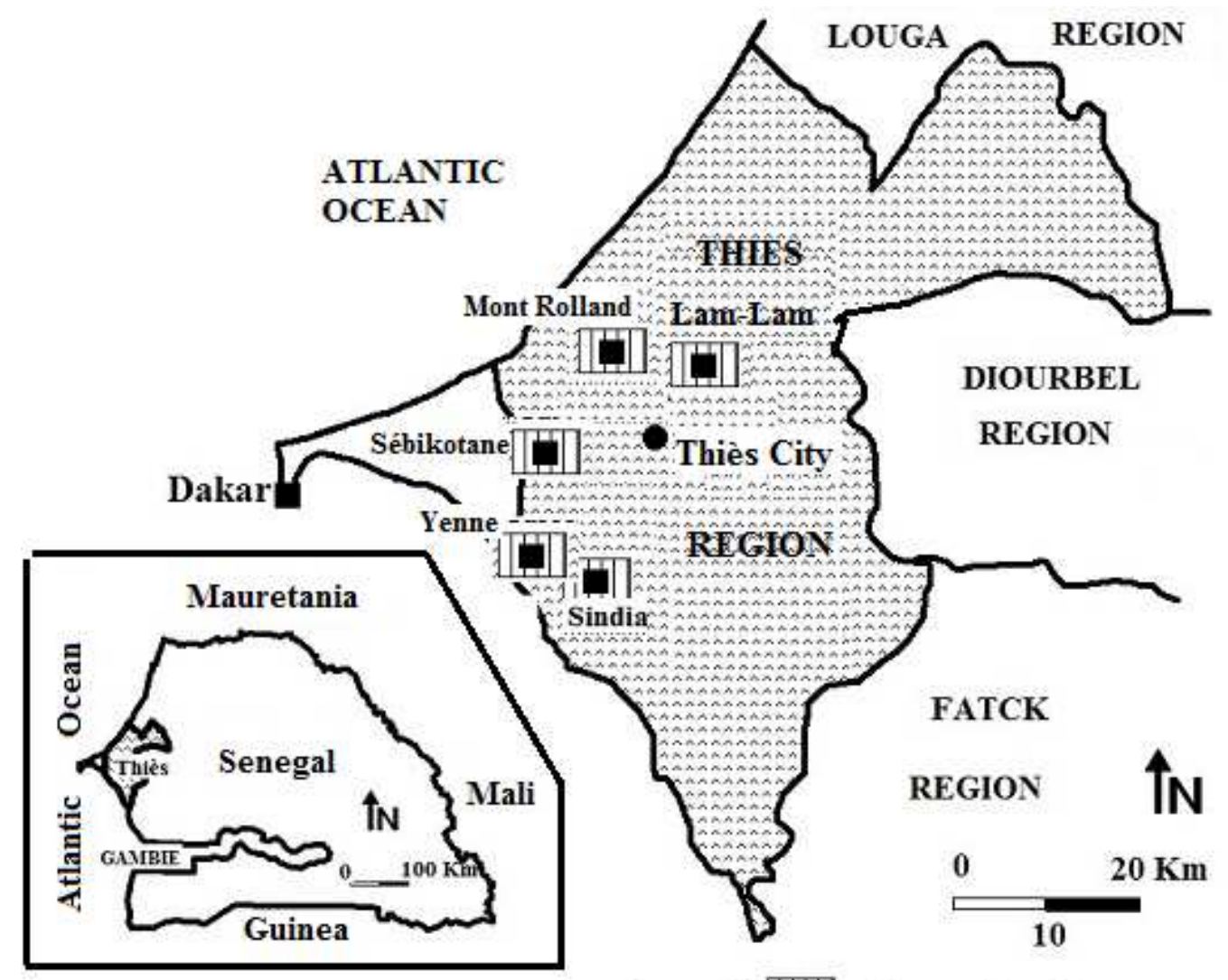

Legend: = Quarry location

Figure 1. Location map showing the different quarry sites within the study area (modified from Diop et al., 2014). 


\section{Results and Discussions}

Particle size analysis: Results of the particle size determination by sieve analysis on the two quarry samples are shown in Figure 2. A comparison in the shape of two curves revealed fairly regular and homogeneous particle size distribution curves. However, samples exhibited different uniformity coefficients $\left(U=d_{60} / d_{10}\right)$ in the order $U=85$ for Lam-Lam sample and $U=110$ for Mont-Rolland sample. About $80 \%$ of the two samples were comprised of pebbles $(60 \mathrm{~mm} \leq \varnothing \leq 4 \mathrm{~mm})$ and granules $(2 \mathrm{~mm} \leq \varnothing \leq 4 \mathrm{~mm})$, while the percentage of fines (grain size fraction less than $\phi 0.08$ $\mathrm{mm}$ ) represented about $10 \%$ in each of the samples (see Table 1). Nonetheless, the samples from Lam-Lam exhibited slightly coarser pebble grade, a lower fraction of fine particles, and better sorting compared to those from MontRolland. The implication of this in terms of behavior of the fabric due to changes in effective stress is discussed in subsequent section below.

Atterberg limits: Values of plastic limit $\left(\mathrm{W}_{\mathrm{P}}\right)$, liquid limit $\left(\mathrm{W}_{\mathrm{L}}\right)$ and plasticity index $\left(\mathrm{I}_{\mathrm{P}}\right)$ derived from index tests performed on the sample fraction passing through sieve $\varnothing$ $400 \mu \mathrm{m}$ are presented in Table 1. Nearly equal Atterberg limits were found for the two samples (Lam-Lam quarry: $\mathrm{W}_{\mathrm{P}}$ $=39.5 ; \mathrm{W}_{\mathrm{L}}=39.5 ; \mathrm{I}_{\mathrm{P}}=18.4$; Mont-Rolland quarry: $\mathrm{W}_{\mathrm{P}}=39$; $\mathrm{W}_{\mathrm{L}}=39 ; \mathrm{I}_{\mathrm{P}}=19$ ), which is an indication of comparable or similar mechanical behavior with respect to the influence of water content. However, it can be inferred from the comparatively lower $I_{P}$ for Lam-Lam sample that the soils occurring in this quarry may gain more strength from the capillary tension of the water meniscus around their contact areas leading to possible increase in effective strength upon the grains and thus the frictional resistance at the points of contact. According to Adeyemi (1995), excessively high plasticity often leads to a common type of road failure in the tropics called «waviness» - a failure which results from plastic flow of wet soil on the application of traffic load. The plots of the Atterberg limits of the tested samples fraction $(\varnothing$ $<400 \mu \mathrm{m})$ in the Casagrande plasticity chart, revealed that the lateritic soils can be classed as " low to medium plastic » inorganic clays and silts materials.

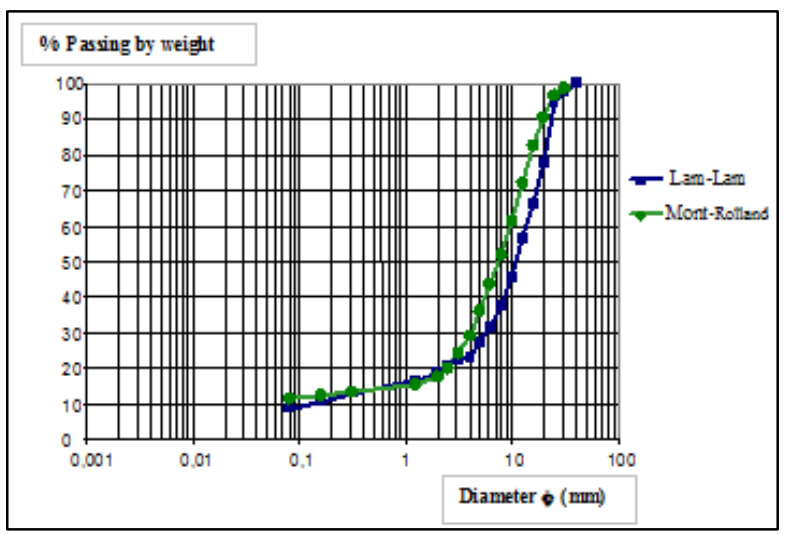

Figure 2. Grain size distribution of test samples.

Table 1. Geotechnical properties of test samples.

\begin{tabular}{|c|c|c|c|c|c|c|c|c|c|}
\hline \multirow[b]{2}{*}{ Sample } & \multicolumn{3}{|l|}{ Granularity } & \multicolumn{3}{|c|}{ Atterberg Limits } & \multicolumn{2}{|c|}{ Proctor test } & \multirow{2}{*}{$\begin{array}{l}\text { CBR test } \\
\text { CBR }\end{array}$} \\
\hline & $\begin{array}{l}\% \text { fraction } \\
\phi<50 \mathrm{~mm}\end{array}$ & $\begin{array}{l}\% \text { fraction } \\
\phi>2 \mathrm{~mm}\end{array}$ & $\begin{array}{l}\% \text { fraction } \\
\phi<0.008 \mathrm{~mm}\end{array}$ & $\mathbf{w}_{\mathbf{L}}$ & $\mathbf{W}_{\mathbf{P}}$ & $\mathbf{I}_{\mathbf{P}}$ & $\begin{array}{l}\text { WOPM } \\
(\%) \\
\end{array}$ & $\gamma d_{\max }(\mathrm{g} / \mathrm{cm} 3)$ & \\
\hline Lam-Lam & 100 & 82 & 9 & 39.5 & 21.1 & 18.4 & 12 & 2,08 & 65 \\
\hline Mont-Rolland & 100 & 82 & 12 & 39 & 20 & 19 & 12.2 & 1.95 & 61 \\
\hline
\end{tabular}

Proctor test: Figure 3 illustrates the results of the Proctor compaction tests. The resulting curves reveal optimum water content (WOPM) of $12 \%$ and corresponding maximum dry density ( $\gamma \mathrm{d}$ max) of $2.082 \mathrm{~g} / \mathrm{cm} 3$ for Lam-Lam sample while the optimum moisture content and maximum dry density are $12.2 \%$ and $1.95 \mathrm{~g} / \mathrm{cm} 3$ respectively for the Mont-Roland sample. Thus, similar optimum water contents at different dry density, is an indication of the fact that the optimum proctor density is presumably dependent on the abundance of fine particles. In other words, it is possible to infer that the Lam-Lam sample containing a smaller percentage of fines $(<$ $9 \%$, as compared to $12 \%$ for the Mont-Rolland sample) will exhibit better performance in relation to road construction. This is consistent with the fact that the larger the fines content, the more cohesive the lateritic soil will be and the higher the water retention capacity which will lead to undrained conditions due to low permeability that will prevent dissipation of pore pressure produced by traffic loading. Therefore it can be concluded that the presence of clays in the study lateritic materials will be a serious constraint due to the higher water absorbing potential and swelling characteristic. According to Tourenq and Tran (1997), clayey materials commonly exhibit a low bulk density because of their high void ratio and porosity; thus may cause a decrease in the mechanical resistance and performance of associated aggregates end-products, particularly under wet conditions.

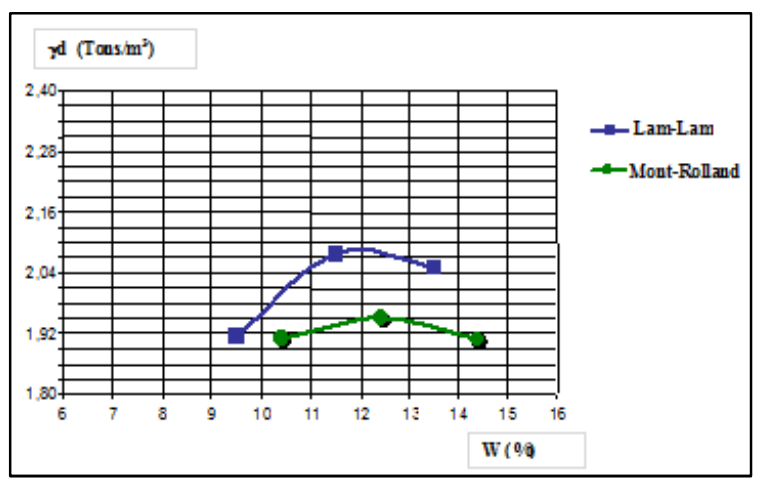

Figure 3. Proctor curves of test samples. 
CBR tests: The plot of the load-bearing capacity values (CBR values) obtained by compaction at $95 \%$ standard Proctor (i.e., to $95 \%$ relative density - $\gamma \mathrm{d}$ max) is presented in Figure 4, while the evaluated mechanical strength of the samples are 65 and 61 for samples from Lam-Lam and MontRolland respectively.

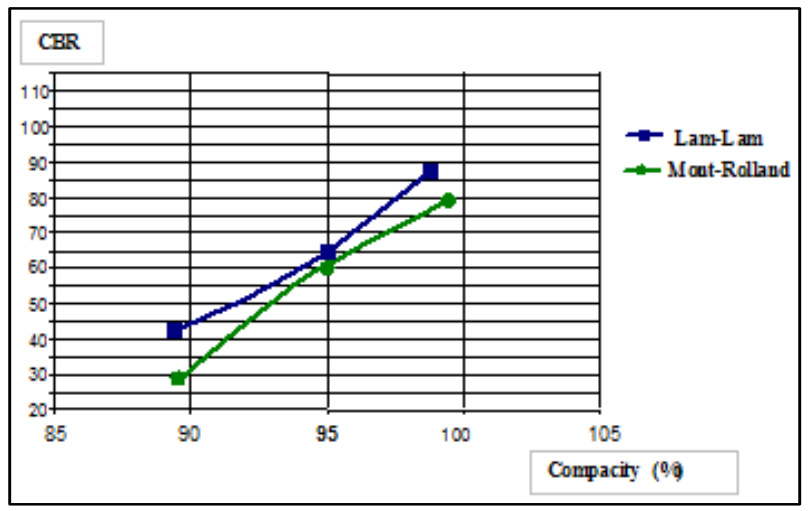

Figure 4. CBR curves of test samples.

These values lie above the threshold value of $C B R \geq 30$ (see Tableau 2; CEBTP, 1980) required for sub-base materials in building foundation, but are much lower than the threshold value of $\mathrm{CBR} \geq 80$ generally recommended for a use in road base courses. In the latter cases, the mechanical properties of these materials require to be improved by treatment (e.g., strengthening their bearing capacity through stabilization with cement), although values of other parameters (for instance $\mathrm{I}_{\mathrm{P}}, \gamma \mathrm{d} \max$ and $\mathrm{W}_{\mathrm{L}}$ ) might be consistent with criteria for use.

Table 2. Relevant geotechnical specifications for the use of lateritic gravels in road construction (CEBTP, 1980).

\begin{tabular}{|c|c|c|}
\hline Parameters & Base course & Sub-base \\
\hline \multicolumn{3}{|c|}{ Reference values } \\
\hline$\gamma_{\mathrm{d} \max }(95 \%$ Std Proctor $)$ & 2.00 (Min.) & 1.90 (Min.) \\
\hline $\mathrm{W}_{\mathrm{L}}$ & 35 (Max.) & 50 (Max.) \\
\hline $\mathrm{I}_{\mathrm{P}}$ & 15 (Max.) & 25 (Max.) \\
\hline \multicolumn{3}{|l|}{ Granularity } \\
\hline Sieve $\varnothing$ & \multicolumn{2}{|c|}{$\%$ passing the sieve } \\
\hline $38 \mathrm{~mm}$ & $85-100 \%$ & $80-100 \%$ \\
\hline $19 \mathrm{~mm}$ & $70-100 \%$ & $65-100 \%$ \\
\hline $10 \mathrm{~mm}$ & $50-95 \%$ & $50-100 \%$ \\
\hline $5 \mathrm{~mm}$ & $40-90 \%$ & $35-100 \%$ \\
\hline $2.5 \mathrm{~mm}$ & $30-80 \%$ & $25-80 \%$ \\
\hline $0.7 \mathrm{~mm}$ & $15-45 \%$ & $15-55 \%$ \\
\hline $0.08 \mathrm{~mm}$ & $5-20 \%$ & $5-35 \%$ \\
\hline \multicolumn{3}{|l|}{ CBR (after 4 days curing) } \\
\hline at $100 \%$ Std Proctor & 80 (Minimum) & \\
\hline at $97 \%$ Std Proctor & & 30 (Minimum) \\
\hline
\end{tabular}

Table 3 presents the results obtained in this study alongside the results from other studies. In summary, the following remarks can be made:

(1) The materials from Lam-Lam quarry are quite similar in physical and mechanical properties with those in Mont-Rolland.
(2) The problem arising from their potential use in road construction is their unfitness for utilization in base courses following the CEBTP's (1980) specifications.

(3) Their bearing capacity (CBR values) and plasticity index (IP) (see Table 3) are generally lower and similar to those of Sindia Quarry elsewhere in the region.

(4) The value ranges of CBR $>80$ for samples collected from Sébikotane and Yenne quarries, reported by Fall (1995) are more suitable for use in road construction compared to the values of CBR 61- 65 for Lam-Lam and Mont-Rolland quarries.

Table 3. Comparison between the main quarries developed in the region.

\begin{tabular}{llllll}
\hline Parameters & $\begin{array}{l}\text { Lam- } \\
\text { Lam }\end{array}$ & $\begin{array}{l}\text { Mont- } \\
\text { Rolland }\end{array}$ & Sébikotane $^{1}$ & Yenne $^{1}$ & Sindia $^{2}$ \\
\hline $\mathrm{W}_{\mathrm{L}}(\%)$ & 39.5 & 39 & 36 & 39,5 & 29.9 \\
$\mathrm{~W}_{\mathrm{P}}(\%)$ & 21.1 & 20 & 16 & 19 & 16.6 \\
$\mathrm{I}_{\mathrm{P}}(\%)$ & 18.4 & 19 & 20 & 20,5 & 13.3 \\
$\gamma \mathrm{d}_{\max }\left(\mathrm{g} / \mathrm{cm}^{3}\right)$ & 2.08 & 1.95 & 2.075 & 1.77 & 2.03 \\
$\mathrm{~W}_{\mathrm{OPM}}(\%)$ & 12 & 12.2 & 8.9 & 8.5 & 9.4 \\
CBR at $95 \%$ & 65 & 61 & 82 & 86 & 64 \\
Std Proctor & 65 & & & & \\
\hline
\end{tabular}

$\left({ }^{1}\right.$ : Source, Fall $1995 ;{ }^{2}$ : Sène, 2013)

Nonetheless, the good quality reserves occurring in Sébikotane and Yenne quarries have been mined out. Therefore, with appropriate treatment and stabilization, the lateritic soils from Lam-Lam and Mont-Rolland quarries can easily serve as an alternative source of laterite in construction activities in Thiès region of Senegal.

\section{Conclusion}

The results of geotechnical examinations of lateritic soils samples from Lam-Lam and Mont Rolland quarries revealed relatively lower values of CBR (load-bearing capacity) as the key technical parameter limiting their suitability for use as aggregates in road construction. The bulk (raw) samples of the lateritic materials do meet the technical design specifications for use as aggregates in road sub-grade building, but does not fulfill the criteria for use in road subbase. The lower CBR values compared to the threshold values designed for a use in road sub-base warrant the need for appropriate treatment to enhance the mechanical performance of the study soils. The observed low CBR can be attributed to the relative abundance of fines particles $(\varnothing \leq$ $400 \mu \mathrm{m})$ that have a tendency to decrease the mechanical resistance and performance of aggregates, particularly under wet conditions. To resume, the studied quarries can be categorized as being of poorer quality materials compared to the depleting reserves developed in Sébikotane and Yenne quarries within the region in terms of both road construction and foundation of structures. However, further experimental tests in respect of best possible treatment (e.g. litho-mixed treatment) and stabilization (e.g. cement stabilization) of the studied soils are recommended, as part of future studies on road structure design processes. 


\section{References}

[1] Adeyemi, G. O. (1995): The influence of parent rock factor on some engineering index properties of three residual lateritic soils in southwestern Nigeria - Bull. Associat. Intern. Géol. de l'Ingénieur, Paris, $\mathrm{N}^{\circ} 52$, pp. 3 - 8.

[2] Bellion Y. \& Guireau R. (1984): Le bassin sédimentaire du Sénégal: Synthèse des connaissances actuelles. In: Plan minéral de la République du Sénégal. BRGM \& DMG Dakar édit., 1, 4-63.

[3] Bohi Z. P. B. (2008): Caractérisation des sols latéritiques utilisés en construction routière: le cas de la région de l'Agnéby (Côte d'Ivoire). Thèse de doctorat, Ecole Nationale des Ponts et Chaussées, Paris, $142 \mathrm{p}$.

[4] CEBTP (1980): Guide pratique de dimensionnement des chaussées pour les pays tropicaux, Ministère de la Coopération (France), 155p.

[5] Crevola G. (1980): Principaux caractères du volcanisme de la presqu'ile du Cap-Vert (Sénégal). 8ème Réunion Ann. Sci. Terre, Marseille, Soc. Géol. France édit., 114 pp.

[6] Diop S., Samb M., Diome F. et Fall M. (2014): Etude de caractérisation des matériaux de la carrière de Sindia (Sénégal occidental) pour une utilisation en géotechnique routière. Revue du Cames SAI, Vol.1, No 2, ISSN 2312-8712, Décembre 2014. doi:10.4236/cames.2014.

[7] Ducasse O., Dufaure Ph. et Flicôteaux R. (1978): Le passage de l'Eocène inférieur à l'Eocène moyen dans la presqu'île du Cap Vert (Sénégal occidental). Révision micropaléontologiques et synthèse stratigraphique. In: Contribution à la connaissance géologique et micropaléontologique de l'Ouest africain. Cahiers de micropaléontologie CNRS Paris, Vol. 1, pp. 3 - 28.

[8] Fall M. (1993): Identification et caractérisation mécanique des graveleux latéritiques du Sénégal: Application au domaine routier. Thèse de doctorat en Génie Civil et Minier, INPLENSG Nancy, France, 204 p.
[9] Fall M., Tisot J.P. et Cissé I. K. (1995): Comportement mécanique à l'appareil de cisaillement de Casagrande de trois graveleux latéritiques compactés provenant du Sénégal occidental. Bull. AIGI, Paris, N 52, pp. 59 - 73.

[10] Flicôteaux R. (1982): Genèse des phosphates alumineux du Sénégal occidental. Etapes et guide d'altération. Mem. Sci. Geol. Univ. Louis Pasteur, Strasbourg, N 67, 220 p.

[11] Michel P. (1976): Les glacis cuirassés d'Afrique occidentale et centrale. In: Colloque «Géomorphologie des glacis». Tours, nov. 1974, Public. Univ. Tours : 70 - 80

[12] Nahon D. (1971): Etude et évolution des cuirasses ferrugineuses quaternaires sur grès : exemple du massif de NDias (Sénégal occidental), Bull. Serv. Carte géol. Als. Lorr. 24, p. $219-241$.

[13] Ngom P. E. S. (2011): Identification des matériaux latéritiques en provenance de Sindia et caractérisation des interfaces dans les structures de chaussée par essai de cisaillement a la boîte de Casagrande, Mem. IST, Univ. C. A. Diop, Dakar, N 222, 48p.

[14] Sène F. (2013): Caratérisation géothechnique du matériau latéritique de Sindia (Sénégal occidental) traité au ciment pour son utilisation en construction routière. Mem. IST, Univ. C. A. Diop, Dakar, $\mathrm{N}^{\circ} 279,44 \mathrm{p}$.

[15] Tessier F. (1965): Les niveaux latéritiques du Sénégal. XXII ${ }^{\text {ième }}$ congr. Intern. Geol, New-Delhi, 1964, et Ann. Fac. Sci., Marseille, 37, (1965), p. 221 - 237.

[16] Tessier F., Flicoteaux, R. and Lappartient, J (1976): Etude géologique de la carrière de Lam-Lam et de ses abords méridionaux (République du Sénégal). Trav. Lab. Sci. Terre St Jérome, Sér. A, Nr 9, 122pp. Marseille.

[17] Tourenq, C. and Tran, N. L. (1997): Assessment of clays in aggregates. A tract for further research. Bull of the International Association of Engineering geology, Nr 56: 97 102, Paris. 